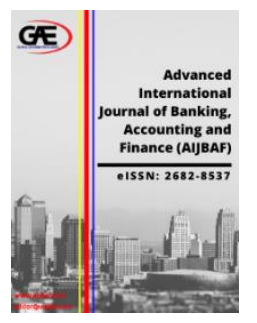

\author{
Advanced International Journal of Banking, \\ Accounting and Finance (AIJBAF) \\ Journal Website: http://aijbaf.com/ \\ eISSN: 2682-8537
}

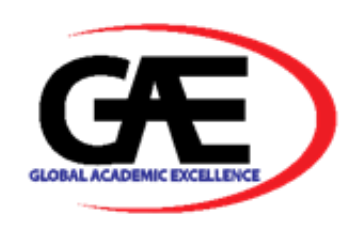

\title{
AMANAH'S PHILOSOPHICAL VALUE IN SHARIA BANKING
}

\author{
Luluk Latifah ${ }^{1}$, Ahmad Zahro ${ }^{2}$
}

1 Faculty Economic; Universitas Islam Sunan Ampel Surabaya, (UINSA) Surabaya Indonesia Email: luluk.delula@gmail.com

2 Faculty Economic; Universitas Islam Sunan Ampel Surabaya, (UINSA) Surabaya Indonesia Email: amakzet@yahoo.com

Article Info:
Article history:
Received date: 07.02 .2020
Revised date: 13.02 .2020
Accepted date: 24.02 .2020
Published date: 13.03 .2020
To cite this document:
Latifah, L., \& Zahro, A. (2020).
Amanah's Philosophical Value in
Shariah Banking. International
Journal of Banking, Accounting, and
Finance, 2 (2), 21-30.

DOI: 10.35631/AIJBAF.22003.

\begin{abstract}
:
The philosophical value of the security is a very great value, which comes from Allah SWT, which is given to his creatures, and humans as the bearer of the highest mandatory value to carry out, maintain and implement it, with security between humans there will be a belief and this trust will ultimately cultivate an inner calm or soul. To find out and measure philosophical values of the trust in both conventional and Islamic banking, then in this study will present the results of the study with respondents divided into two groups, the first group is those with a bachelor's degree in general and the second group is those who have S2 degrees and doctoral candidates for Islamic Economics. Quantitative research methods, with frequency distribution and cross-tabulation of selected variables with data analysis using SPSS. Based on the results of the study, the values of security from the highest to the lowest are: In the first group of respondents, the values of security from the highest to the lowest are: (1) Value of Maintaining Trustworthiness, Islamic Banks get a value of 4.42 and a conventional bank of 3.67. (2) The value of responsible Islamic banks is 4.00 and conventional banks are 3.08. (3) The value of maintaining bank secrets, Islamic Banks is 3.92 and conventional banks are 3.83. (4) The trust value of Islamic Banks is 3.58 and conventional banks are 2.42. (5) Honest Value, carrying out the assignment of 2.17 for Conventional Banks and (6) Trust value in delivering messages 3.33 for Conventional Banks at Islamic Banks has the same value of 3.42. In the second group of respondents (1) The value of safeguards of customer secrets, Islamic banks get the highest value of 4.70 . whereas Conventional Bank 4.0. (2) The value of guarding the customer's trust, Islamic banks get a value of 4.50 and Conventional Bank 3.60. (3) Value of liability, Islamic banks 4.40 and Conventional Banks 3.90. (4) Value can be trusted, Islamic banks get a value of 4.20, and Conventional Banks 3.40. (5) The value of honesty and ability to perform tasks, Islamic banks get a value of 4.10, while in conventional banks is the lowest value of 1.70 .
\end{abstract}




\section{Introduction}

Philosophical value is the value of thinking critically to find solutions to various problems in achieving a better life. The solution used is not just the origin of sound but must go through mature and critical thinking. The philosophical values of the amanah in sharia banking, are values that can be explored in the nature of the amanah in sharia banking when performing its functions in accordance with Islamic sharia principles. The function of banking activities both conventionally and syariah is divided into three, namely the function of accepting deposits, lending or channelling money in providing financing and transferring or sending money. In this study, it will be known how and how much the philosophical value of the amanah in sharia banking is using the cross-tabulation method of selected variables with data analysis using SPSS. and supported by in-depth analysis through a research library about the philosophical values of the amanah in sharia banking.

\section{Literature Review}

\section{Amanah Philosophical Value}

Etymologically the word amanah is from Arabic (amine, amana) which means honest or trustworthy. taken from the root word: "امن - يامن - امانه : then form the word to be which has the meaning of trust, straight, honest, loyal. In terminology according to Abu alBaqa al-Kafumi the trust is all obligations imposed on a servant. If according to Muhammad Rasyid Rid'a trust is a trust aimed at others so that peace of mind appears. Fakhr al-Di'n alRa'zi said that trust is an expression of a right that must be fulfilled by others. The opinion of Abu Hayya al-Andah, said that all the Shari'a of Allah were trustworthy and al-Qurtubi said that the peak of trust was the preservation and implementation.

From the explanation above about the meaning of the trust both etymologically and in terminology from the experts, it can be underlined that the trust is something very grand whose existence can make peace in the soul.

Lafaz amanah when seen in the Qur'an which refers to the meaning of belief, is repeatedly mentioned many times, and mostly in the form of isim or nouns, only a few lafaz in the form of fi'il or command words. Substantially, to further explore the meaning of the amanah can be seen in the contents of the content in the Qur'an which is mapped as below:

The order to convey and carry out the amanah listed in the QS. al-Baqarah verse: 283:

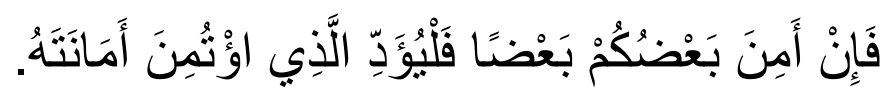

Meaning: "If some of you believe in others, then let those who are trusted fulfill their amanah (debt)."

and listed in QS an-Annisa paragraph: 58: 


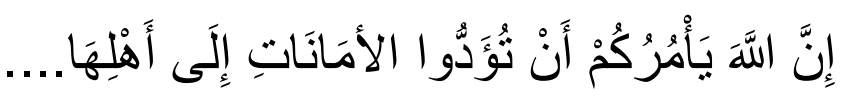

Meaning: "Verily, Allah tells you to deliver the mandates to their owners"

From the two verses above, the order to convey the amanah and fulfil the amanah comes directly from Allah SWT, so this should not be considered trivial or simple. This is the legal basis for building trust in the field of law, especially in developing Islamic law.

About maintaining Amanah, listed in QS Al-Mu'minun verse 8

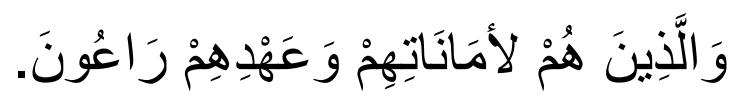

Meaning: "And those who keep the amanah (which they bear) and their promises."

From the above verse implies that maintaining the trust is the nature of people who believe, and the maintenance of the trust is not dependent on time. And if it does not maintain the amanah or betrayal, then it is classified as an unbeliever and can even be included in one of the categories of signs of a hypocrite, namely if it is believed, then betrayed.

About betraying Amanah. listed in QS Al-Anfal verse 27

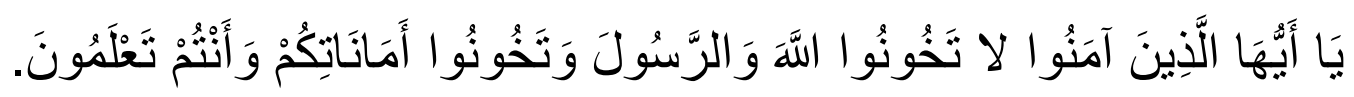

Meaning: "O you who believe, do not betray Allah and the Apostle, nor do you betray the messages entrusted to you, while you know."

In this verse it is explained that the betrayal of the amanah is the same as the betrayal of Allah and his Apostles, thus it can be seen that how great the position of the amanah on the side of Allah SWT, because the betrayal of the amanah is equated with the betrayal of Allah SWT and his Rasul.

About the amanah that must be shouldered by humans, Listed in Surah Al-Ahzab verse 72:

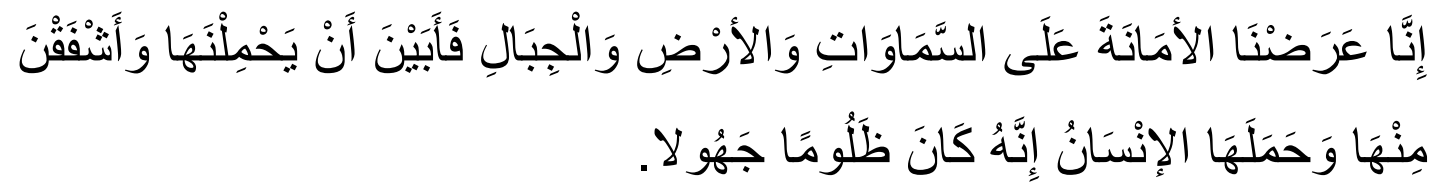

Meaning: "Verily, we have revealed the message to the heavens, the earth and the mountains, so all are reluctant to carry the amanah and they are afraid that they will betray it, and that the amanah is carried by humans. Truly humans are very wrong and very ignorant. "

In the above verse it is explained that humans are the only beings who are denounced (very unjust and very stupid), because they accept the amanah from Allah SWT, while other creatures (heaven, earth and mountains) reject it when offered the amanah. According to commentators, what is meant by humans is the majority of humans not every individual human being.

The substance of the trust is the trust given by others to someone so that the trust will lead to peace of mind, because someone who is given the trust will fulfil the amanah so that the person giving the trust is not worried, and it is this worry that can ultimately lead to mental or inner peace. So that the amanah indirectly leads to inner calm, because philosophically security will 
lead to a belief, and trust causes inner peace. The relationship of the three can be described as a wheel below:

\section{Figure 1: Relationship Between Amanah, Trust And Peace Of Mind}

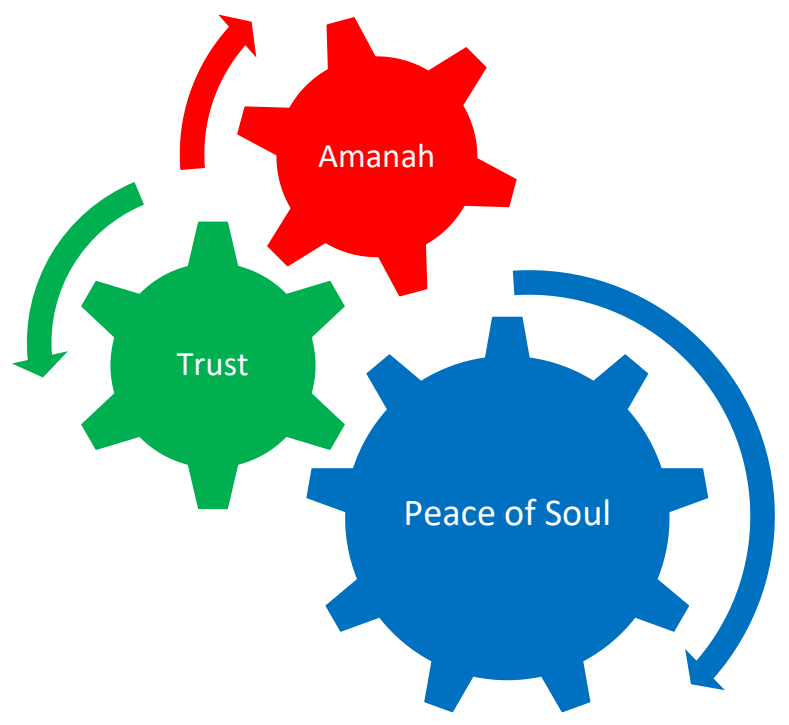

\section{Understanding Bank And Its Function}

Bank according to the language come from the Italian word "banco" which means table. In the 13th century bank employees at that time carried out their work activities in serving customers (savers) by sitting behind a desk (banku/table). Sitting while working or working while sitting, especially behind a desk (banku) at that time is very strange because most people's work at that time does not allow them to sit while working. So, if there are bank employees at the time who are sitting in carrying out their work make a strange thing. The term banku is increasingly popular and finally officially bench as the meaning of the word "banco" to be a bank, until now.

The banking function can be grouped into 3, namely 1) The function of recipient of deposits, namely banks as recipients of money and funds from the public in the form of deposits or savings, deposits, current accounts or checking accounts. 2) Function as channelling funds, namely banks as channelling credit or loans to the public without question whether the recipient of the credit is the person who deposits the money or saves the money or not. 3) Function as a money transfer service, namely the bank as an agent of trust, which is to provide services in the form of securing the control of assets, whether individuals, groups or companies.

\section{Bait Al-Mal and The Banking Practices of The Prophet Muhammad and His Companions}

Rasulullah SAW was the first head of state to introduce a new concept in the field of state finance in the 7th century. All revenues from the state must be collected first into one place and then spent according to the needs of the country. The status of the collected assets belongs to the state and the place to collect the assets of the state is called "Baitul Mal" or "Bait al-Mal" or treasure house. The treasures stored in Bait al-Mal at a certain time are distributed to the community until there is no trace left. 
The function of Bait at-Mal, among others: 1) As an institution for storing assets used as state treasury that is needed by the community at any time and used by the Khalifah for the benefit of its people 2) Building the progress of the Islamic state in various fields. 3) Funding all the needs and problems that exist in Islamic government.

Events that show the existence of modern banking functions that already existed at the time of the Prophet and friends, namely: 1) Storage function (Deposit). The arrival of Abu Hurairah who deposited the wealth into the Bait at-Mal and kept it as a reserve until one day could be destined for the needs of the people. 2) The function of depositing wealth, Rasulullah SAW, known by the nickname al-Amin, is trusted by the people of Mecca to save their treasures, so that at the last moment they want to migrate to the city of Medina, the Prophet asked Ali ibn Abi Talib to return all the assets deposited to the owner. 3) The Financing Function, when Zubair bin al-Awwam, chose not to receive the assets. He preferred to receive it in the form of a loan, and the Khalifah Period Umar bin Khattab was once visited by Hindun bin Utbah who wanted to borrow the treasures of Bait at-Mall in the amount of 4,000 dirhams for trade and guaranteed to return it. 4) Transfer and Use Check Function, when the Khalifah Umar bin Khattab used checks to pay benefits to those who were entitled.

The main functions of modern banking, have become an inseparable part of the lives of Muslims since the time of the Prophet, although the term bank was not known at that time either during the time of the Prophet Muhammad, the time of al-Khulafaur Rashdin, the Umayyad dynasty and the Abasiyah dynasty.

In subsequent developments, the activities of one of the banking functions carried out by individuals (jihbiz) are carried out by an institution that is currently known as a bank or banking institution.

From the scheme below it can be explained that the embryo of banking activities in the Islamic community has existed since the time of the Prophet Muhammad. This banking process has evolved from time to time. Activities of banking functions carried out individually both by the Messenger of Allah and by friends where one individual carries out a single banking function became developed during the Abasiyah period carried out by Jihbiz.

Figure 2: Evolution of Banking Activity in Islamic Communities

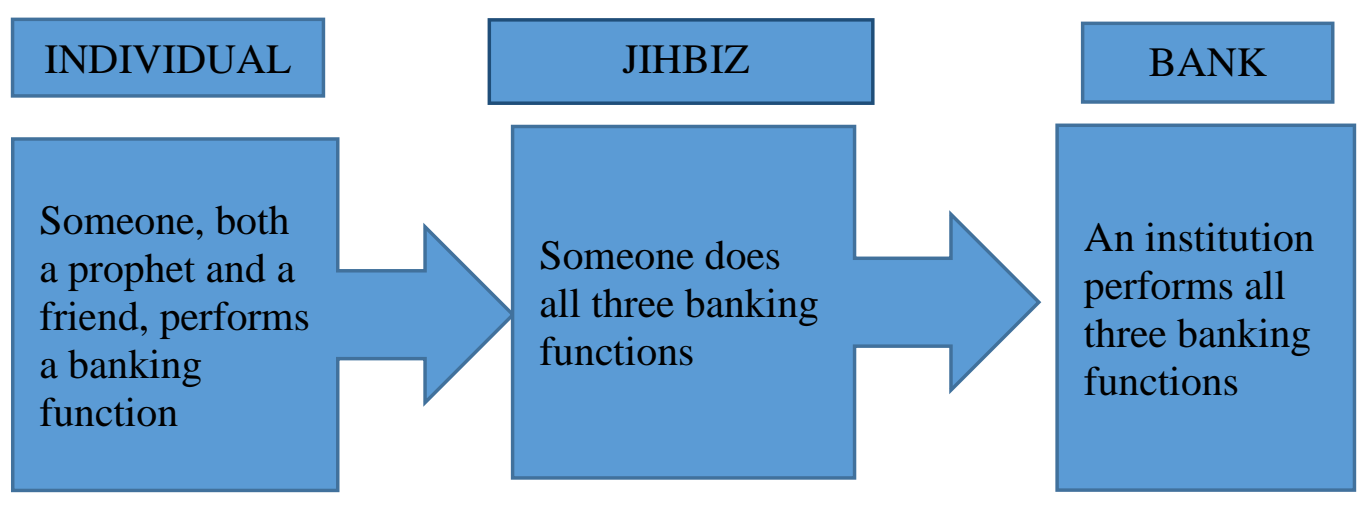

Jihbiz has carried out all three banking functions at once, and over time this activity became an institution after the activity was adopted by European society in the Middle Ages on an interestbased basis, the institution came to be known as a Bank known until this modern era. 
At the time of the middle ages that Islamic civilization began to experience a setback and colonialism of western nations against Muslim countries to make the evolution of shariacompliant banking practices had stopped for several centuries. And only developed again when several Muslim countries became independent and formed a modern Islamic bank in several countries, for example in Malaysia in the mid-1940s but failed, then in Pakistan in the late 1950s established credit institutions in rural areas without interest, even this was less successful, until the most successful was in Egypt in 1963 with the founding of Mit Ghamr Local Saving Bank.

Mit Ghamr Local Saving Bank was warmly welcomed in Egypt, especially among farmers and rural communities although it had suffered a setback and was taken over by the National Bank of Egypt and the Central Bank of Egypt in 1967 and the concept of no interest began to be abandoned, but in 1971 through the founding of Naser Social The bank revived the concept without interest and returned to the concept by Mit Ghamr. Mit Ghamr inspires Muslims throughout the world and raises awareness that Islamic principles are in fact still applicable in modern business, especially in the banking world, until finally the Islamic Development Bank (IDB) was formed in October 1975 which was overseen by 22 Islamic countries included in the membership of the OIC (Organization of Islamic Conference).

\section{Research Methodology and Results of Philosophical Value Measurement of Sharia Banking}

\section{Overview of Research}

This research is a quantitative study, survey method, and statistical analysis using frequency distribution and cross tabulation of selected variables with data analysis using SPSS. The sample in this study were respondents with a minimum education level of S-1 which were grouped based on their education and knowledge of sharia economics, specifically knowledge of sharia banking.

This research was conducted by distributing questionnaires as many as 14 items on social media in the form of WA (WhatsApp) Group consisting of bachelor-educated groups, bacheloreducated groups and groups who are still pursuing doctoral education specifically in sharia economics. Respondents who have received questions are expected to fill in with numbers 1-5 which is a Likert scale, where the value of 1 (strongly disagree), value 2 (slightly disagree), value 3 (quite agree), value 4 (agree) and value 5 (strongly agree)

\section{Research and Analysis Results}

Basic knowledge of respondents about banking, Respondents' opinions on: "The establishment of sharia banking is a milestone in the start of sharia economy. "The results of the study showed that $60 \%$ of respondents who were studying doctoral education in sharia economics stated strongly agree and 30\% agreed, only $10 \%$ stated less agree. While respondents not all backgrounds in Islamic economics, having the opposite opinion of $66.6 \%$ expressed strongly disagree and disagree, only $8.3 \%$ stated strongly agree. This is very interesting, that the two groups of respondents have the same education at a tertiary level, but their opinions are very contradictory or different just because one of them has a background in Islamic economic education and the other is mixed education.

Respondents' opinions on: "All banking is the same both sharia and non-sharia." a large portion of respondents who were undergoing doctoral education is $80 \%$ compared with 
respondents who have a general tertiary education background of around $50 \%$, or a difference of about $30 \%$.

Respondents' opinions about: "I tend to save at home instead of banking." $60 \%$ of respondents who are taking doctoral programs say they strongly disagree when saving at home, whereas for respondents who have higher education and masters backgrounds have opinions that spread between strongly agree and strongly disagree having the same average percentage of between $16 \%-25 \%$, this means that they have a tendency to save not in banking and also at home are both the same alternative choices.

Respondents' opinions about: "Happy with the existence of Islamic banks in Indonesia." 90\% of respondents who are indeed concentrated on the doctoral program in sharia economics stated very much agree, and the remaining $10 \%$ stated quite agree. Whereas for the first group of respondents with a general background of $50 \%$ who strongly agreed, and $41.7 \%$ stated quite agree, there were even $8.3 \%$ who disagreed.

The large percentage who disagree with the existence of sharia banking in Indonesia can be due to the background of respondents who have never been related to sharia banking because they may indeed not know but just know it. This can be strengthened from the results of the table: 3 above the average savings they do at home.

Respondents' opinions about: "I prefer Islamic banks for inner peace." Then the result is 50\% of respondents who come from Islamic economics doctoral candidates expressed strongly agree, $40 \%$ agreed and $10 \%$ stated less agree, whereas in the first education respondent group $41,7 \%$ stated strongly agree and the rest on average expressed less agree even some stated strongly disagree.

Researchers concluded that those who disagreed and strongly disagreed were those who argued that between conventional banks and Islamic banks were the same.

\section{Evaluation of Respondents Regarding the Value of the Philosophy of Amanah.}

Table 1: Average Value of Amanah

\begin{tabular}{|l|r|r|r|r|}
\hline \multirow{2}{*}{ Information } & \multicolumn{4}{|c|}{ Level of education } \\
\cline { 2 - 5 } & \multicolumn{2}{|c|}{1} & \multicolumn{2}{c|}{$\mathbf{2}$} \\
\cline { 2 - 5 } & \multicolumn{1}{|c|}{ BS } & \multicolumn{1}{c|}{ BK } & \multicolumn{1}{c|}{ BS } & BK \\
\hline 1. Can be trusted & 3,58 & 2,42 & 4,20 & 3,40 \\
\hline 2. To be responsible & 4.00 & 3,08 & 4,40 & 3,90 \\
\hline 3. Maintain trust & 4.42 & 3,67 & 4.50 & 3,60 \\
\hline 4. Honestly, doing errands & 3.42 & 2,17 & 4.10 & 1,70 \\
\hline 5. Deliver a message & 3,42 & 3,33 & 4,30 & 3,90 \\
\hline 6. Keep customers & 3.92 & 3,83 & 4,70 & 4,0 \\
confidential & & & & \\
\hline
\end{tabular}




\begin{tabular}{|l|r|r|r|r|}
\hline Average & 3,79 & 3,001 & 4,37 & 3,41 \\
\hline
\end{tabular}

Source: Processed Results of SPSS September 2019

From the six security values examined, according to the table: 1 above, the highest average value is 4.70, which is the value of safeguarding the secrets of customers in Islamic banks, then followed by the value of 4.50, namely the value of maintaining trust in Islamic banks, then 4 , 40 that is responsible, 4.20 is trustworthy and 4.10 is honest and able to perform tasks that are precisely the conventional bank is the lowest value of 1.70 this value is the lowest value among all research results both on the opinion of respondents who are doctoral candidates Islamic economics and the opinions of respondents who have a general background.

\section{Average Value of Respondents to The Functions Carried Out Banking}

In theory, which has been elaborated in the discussion above, it is stated that there are 3 kinds of banking functions, in table 2 below will be seen the results of research on respondents' opinions about the three banking functions on Islamic banks and conventional banks.

Table 2: Average Respondent Values of Functions Performed in Banking

\begin{tabular}{|l|r|r|r|r|}
\hline \multirow{2}{*}{ Information } & \multicolumn{3}{|c|}{ Level of Education } \\
\cline { 2 - 5 } & \multicolumn{2}{|c|}{1} & \multicolumn{2}{|c|}{$\mathbf{2}$} \\
\cline { 2 - 5 } & BS & BK & BS & BK \\
\hline $\begin{array}{l}\text { 1. Able to perform customer deposit and deposit } \\
\text { functions }\end{array}$ & 4,25 & 3,67 & 4,80 & 4,50 \\
\hline 2. Able to perform payment functions & 3,83 & 3,75 & 4,60 & 4,60 \\
\hline 3. Able to do the financing function & 3,58 & 3,50 & 4,40 & 4,30 \\
\hline \multicolumn{1}{|c|}{ Average } & $\mathbf{3 , 8 9}$ & $\mathbf{3 , 6 4}$ & $\mathbf{4 , 6 0}$ & $\mathbf{4 , 4 7}$ \\
\hline
\end{tabular}

Source: Processed Results of SPSS September 2019

In the table: 1 above, both Islamic banks and conventional banks on average have almost the same value in the opinion of the respondents both respondents of Islamic economics doctoral candidates and respondents who have a background in general, the average value ranges between $3.58-4,80$. if sorted from the largest to the smallest average value, it can be arranged as below: 1) The function is able to perform the function of deposits and customer deposits an average value of 4.80 in Islamic banks. 2) Able to perform payment functions to customers, the value of 4.60 in Islamic banks and conventional banks has the same value. 4) Able to perform financing functions, average value of 4.40 in Islamic banks.

\section{Conclusion}

The philosophical value of security is a very great value, which comes from Allah SWT, which is given to his creatures, and humans as the bearer of the highest mandatory value to carry out, maintain and implement it, with security between humans there will be a belief and this trust will ultimately cultivate an inner calm or soul.

Three banking functions according to experts and according to banking law are: save, distribute and transfer. Since the time of the Messenger of Allah and his companions in the practice of 
Muamalat activities at that time had performed one of the banking functions including the contract, only when that one function was carried out by one person, only during the Abasiyah dynasty one person could perform the 3 known banking functions with Jihbiz. And later in the Middle Ages when the decline of Islamic countries due to western colonialism, these functions were adopted by Western societies (Europe) and developed into interest-based banks or banks to date.

The banking security values from the highest to the lowest are: 1) The value of safeguarding customer secrets, Islamic banks get the highest value of 4.70.2) The value of safeguarding the trust of customers, Islamic banks get a value of 4.50 3) The value of responsibility, Islamic banks 4.40.4) Value can be trusted; Islamic banks get a value of 4.20. 5) The value of honesty and ability to perform tasks, Islamic banks get a value of 4.10. and in conventional banks the lowest value is 1.70 .

\section{References}

Abu Hayyan Muhammad ibn Yusuf al-Andalusi (1413H/1993M). Al-Bahjr al-Muht, juz VII, cet 1. Beirut: Dar al-Kutub al-ilmiyyah,

Abu Abdillah Muhammad ibn ahmad Syams al-Din al-Qurtubi, (1384 H/ 1964M). al-Jami' li Ahkam al-Qur'an juz XII, cet. II, Mesir: al-Qahirah Dar al-Kutub al-Misriyyah,

Abu al-Baqa Ayyub ibn Musa al-Husaini al-Kafu. (1419H/1998M). Mu'jam Fii al Mustalahat wa al-Furuq al-Lugawiyah. Beirut: Muassasah al-Risalah,

Agung, Ivan Muhammad dan Desma Husni, (2016). Pengukuran Konsep Amanah dalam Pendekatan Kualitatif dan Kuantitatif. Jurnal Psikologi, Volume 43, No.3

Abdullah, Thamrin dan Francis Tantri. (2013). Bank dan Lembaga Keuangan. Jakarta: PT RajaGrafindo Persada,

Departemen Pendidikan Nasional. (2008). Kamus Besar Bahasa Indonesi. Jakarta: Pusat Bahasa Departemen Pendidikan Nasional

Fauzia, Ika Yunia \& Abdul Kadir Riyadi. (2014). Prinsip Dasar Ekonomi Islam: Perspektif Maqasid al-Shar'ah. Jakarta: Prenadamedia Group.

Idri. (2015). Hadis Ekonomi: Ekonomidalam Perspektif Hadis Nabi. Jakarta: Prenada Media Group.

Imaniyati, Neni Sri. (2013). Perbankan Syariah: dalam Perspektif Hukum Ekonomi.Bandung: Mandar Maju,

Jaribah bin Ahmad Ak-Harits. (2006). Fikih Ekonomi Umar bin Al-Khatab. Jakarta. PustakaAl-Kautsar.

Karim, Adiwarman Azhar. (2015) Ekonomi Makro Islami. Jakarta: PT RajaGrafindo Persada,

Karim, Adiwarman Azhar. (2016). Bank Islam: Analisis Fiqih dan Keuangan (ed. Kelima). Jakarta: PT RajaGrafindo Persada,

Karim, Adiwarman Azhar. (2014). Sejarah Pemikiran Ekonomi Islam.Jakarta: PT RajaGrafindo Persada,

Muhmud, Yunus. (2007). Kamus Arab Indonesia, Ciputat: PT Mahmud Yunus Wa Dzurriyah, Muhammad Rasyid ibn 'Ali Rida. (1990). Tafsir al-Manar juz V. Mesir: al-Haiah alMisriyyah al-Ammah li al-kitab,

Muhammad Fakhr al-Din al-Razi. (1401 H/1981M). Mafatih al-Gaib, Juz X, cetakan 1. Beirut: Dar al-Fikr,

Ridwan, Ahmad Hasan. (2013). Manajemen Baitul mal watamwil. Bandung: CV Pustaka Setia, Rozalinda. (2016). Fikih Ekonomi Syariah. Jakarta: PT RajaGrafindo Persada,

Sholihin, Ahmad Ifham. (2010). Buku Pintar Ekonomi Syariah. Jakarta: PT Gramedia Pustaka Utama, 
Soemitra, Andri. (2012). Bank \& Lembaga Keuangan Syariah. Jakarta: Prenada Media Group,

Sukron, Kamil. (2016). Ekonomi Islam: Kelembagaan, dan Konteks Keindonesiaan. Jakarta: PT RajaGrafindo Persada, 2016.

www.ojk.co.id (2017). Sejarah perbankan Syariah. diunduh 9 maret

www.ekonomi.com (2017) Pengertian Bank diunduh 9 maret 